\title{
The efficacy and value of emergency medicine: a supportive literature review
}

\author{
C James Holliman ${ }^{1 *}$, Terrence M Mulligan ${ }^{2}$, Robert E Suter ${ }^{3}$, Peter Cameron ${ }^{4}$, Lee Wallis ${ }^{5}$, Philip D Anderson ${ }^{6}$ and \\ Kathleen $\mathrm{Clem}^{7}$
}

\begin{abstract}
Study objectives: The goal of this study was to identify publications in the medical literature that support the efficacy or value of Emergency Medicine (EM) as a medical specialty and of clinical care delivered by trained emergency physicians. In this study we use the term "value" to refer both to the "efficacy of clinical care" in terms of achieving desired patient outcomes, as well as "efficiency" in terms of effective and/or cost-effective utilization of healthcare resources in delivering emergency care. A comprehensive listing of publications describing the efficacy or value of EM has not been previously published. It is anticipated that the accumulated reference list generated by this study will serve to help promote awareness of the value of EM as a medical specialty, and acceptance and development of the specialty of EM in countries where EM is new or not yet fully established.
\end{abstract}

Methods: The January 1995 to October 2010 issues of selected journals, including the EM journals with the highest article impact factors, were reviewed to identify articles of studies or commentaries that evaluated efficacy, effectiveness, and/or value related to EM as a specialty or to clinical care delivered by EM practitioners. Articles were included if they found a positive or beneficial effect of EM or of EM physician-provided medical care. Additional articles that had been published prior to 1995 or in other non-EM journals already known to the authors were also included.

Results: A total of 282 articles were identified, and each was categorized into one of the following topics: efficacy of EM for critical care and procedures (31 articles), efficacy of EM for efficiency or cost of care (30 articles), efficacy of EM for public health or preventive medicine (34 articles), efficacy of EM for radiology (11 articles), efficacy of EM for trauma or airway management (27 articles), efficacy of EM for using ultrasound (56 articles), efficacy of EM faculty (34 articles), efficacy of EM residencies (24 articles), and overviews and editorials of EM efficacy and value (35 articles).

Conclusion: There is extensive medical literature that supports the efficacy and value for both EM as a medical specialty and for emergency patient care delivered by trained EM physicians.

\section{Introduction Background}

Emergency Medicine (EM) is an officially recognized medical specialty in over 60 countries, with the rate of specialty recognition accelerating in recent years [1]. Recent epidemiologic and demographic public health data highlight the growing need for EM, trauma, and acute care development in all countries across the

\footnotetext{
* Correspondence: jholliman@cdham.org

'The Center for Disaster and Humanitarian Assistance Medicine, Uniformed Services University of the Health Sciences, and George Washington University School of Medicine and Health Sciences, Bethesda, MD, USA Full list of author information is available at the end of the article
}

socioeconomic spectrum. According to the 2006 World Health Organization studies on the Global Burden of Disease [2], worldwide demographic and epidemiologic shifts now show non-communicable diseases to have become the single largest cause of morbidity and mortality worldwide. Stroke, cardiovascular disease, cancer, and trauma have, for the first time, surpassed communicable diseases and are listed as the major global causes of death and disability. EM care delivery systems are specifically focused on managing the acute consequences of non-communicable as well as communicable disease processes, and therefore represent an important public health tool for reducing the present and future global

\section{SpringerOpen ${ }^{\circ}$}


disease burden, similar to the effect that immunization programs and other public health initiatives have had on communicable disease in the past [3]. In countries where EM has been well established as a medical specialty for decades, the value of EM specialty training and an emergency care system staffed by EM specialists may seem self-evident to all stakeholders within the healthcare system; however, in countries where EM is still not yet well established or recognized as a medical specialty, this is often not the case. Opponents of EM specialty recognition in countries without EM have argued that there is no scientific evidence that an EM specialtybased emergency care system would provide measureable benefit. EM specialist physicians and other advocates for better emergency care in countries with established EM specialties have long understood and accepted the relationship between EM specialty recognition, EM specialty training and improved emergency care delivery. Therefore, there has not been a motivation or need in these countries to systematically prove the value and benefit of EM specialty-based emergency care systems as compared with non-EM specialty-based emergency care systems any more than other established medical specialties are compelled to justify their existence. However, in countries where EM is new or not yet recognized, there may be a lack of awareness of the benefits of EM specialty-based emergency care among healthcare policy and decision makers, so there is a need to systematically summarize the evidence supporting the benefit of EM, in order to facilitate the process of gaining official approval, adoption, or recognition of EM as a specialty.

In countries where EM has been well established and officially recognized, EM has such close and extensive interactions with the rest of the health care system and with other specialties that documenting the direct effects of EM alone is problematic. Performing "before and after" studies of the efficacy of newly introducing EM to many countries has also been challenging because of the poor quality and reliability of health outcome data in these countries prior to the introduction of EM. Despite these challenges, the authors found that an extensive body of medical literature has been published over the past several decades that supports the value of EM specialty-based emergency care delivery systems. The main aim of the project reported in this manuscript is to correct the misconception that there have been few publications to date that support the value of EM.

\section{Importance}

The authors undertook the "Efficacy of EM Project" described in this manuscript to provide compiled reference articles that support EM efficacy and value. It is hoped that this review of some of the supportive literature and references will be useful in promoting the establishment, recognition, and continued development of EM in countries where the specialty is still forming, as well as in countries where it already exists.

\section{Goals}

The goals of this study were to accumulate a reference list of articles from selected medical journals that supported the efficacy, effectiveness, an or value of EM as a medical specialty or of clinical care delivered by trained EM physicians. In this study we use the term "value" to refer both to the "efficacy of clinical care" in terms of achieving desired patient outcomes as well as "efficiency" in terms of effective and/or cost-effective utilization of healthcare resources in delivering emergency care.

\section{Methods}

The tables of contents of selected journals that are concerned mainly with EM or its subspecialties were reviewed back to 1995 , or the publication start date of the journal, whichever was later, to identify articles that were relevant to the efficacy or value of the specialty of EM. In addition, relevant "landmark" articles already known to the authors that were published prior to 1995 or in other non-EM journals were included as well. Full text of these articles was then obtained through an electronic medical library system and the first author reviewed the text of each article to verify its relevance for inclusion. Articles were selected for inclusion if they showed a positive or beneficial effect of EM or of EM physician-provided medical care. Articles were then verified for inclusion by consensus of the authors, and all authors agreed on the inclusion of all the articles in the final compilation. Articles about prehospital care not provided by physicians were not included. The selected articles were grouped into nine different topic categories. Since this study was only comprised of a journal article review, it was exempt from institutional review board approval.

The journals reviewed included Annals of Emergency Medicine, Academic Emergency Medicine, the American Journal of Emergency Medicine, and the Journal of Emergency Medicine from August 2010 back to January 1995, Prehospital and Disaster Medicine from July 2010 back to January 2002, the Western Journal of Emergency Medicine and the International Journal of Emergency Medicine from July 2010 back to their start dates in 2008, and the European Journal of Emergency Medicine from October 2010 back to January 1995. Several other prominent EM journals were not reviewed for this study simply because the authors did not have electronic access to the full text of all their articles. 
The decision to limit this review to primarily articles published after 1994 was based on consensus by the authors that many articles published prior to 1995 were either no longer directly relevant or the same subject content had been repeated in more recent publications.

Articles selected for inclusion in this review addressed a study or summary analysis related to showing the efficacy or value of EM or aspects of EM delivered care. Case reports and case series of successful clinical care in the Emergency Department (ED) were not included (there are of course thousands of these types of published reports in the medical literature). Articles were then subclassified into one of the nine categories listed below. If an article addressed more than one aspect of EM efficacy or effectiveness it was placed in the single category deemed most applicable by the reviewer. Each article was only placed into a single category even if it addressed more than one aspect of EM efficacy.

1. Efficacy of EM for critical care and procedures

2. Efficacy of EM for efficiency or cost of care

3. Efficacy of EM for public health and preventive medicine

4. Efficacy of EM for radiology (i.e., accuracy of reading films, etc.)

5. Efficacy of EM for trauma and airway management

6. Efficacy of EM for using ultrasound

7. Efficacy of EM faculty

8. Efficacy of EM residencies

9. Overviews and editorials of EM efficacy or value.

\section{Results}

A total of 282 articles related to the efficacy of EM were identified with the following numbers of articles in each subcategory (see reference list for citation specifics):

1. Critical care and procedures: 31 [4-34]

2. Efficiency or cost of care: 30 [35-64]

3. Public health and preventive medicine: 34 [65-98]

4. Radiology: 11 [99-109]

5. Trauma and airway: 27 [110-136]

6. Ultrasound: 56 [137-192]

7. EM faculty: 34 [193-226]

8. EM residencies: 24 [227-250]

9. Overviews and editorials: 35 [251-285].

Of note, while not an aim of the study, the authors identified only three articles with negative evaluations of EM; these were not included in the final compiled list.

\section{Discussion}

This review of selected medical literature since 1995 with the compilation of articles supporting the efficacy or value of EM shows that there are an extensive number of published references for each subcategory supporting the efficacy and value of EM. The content and conclusions of the articles in the sets identified above provide support for the following statements (listed in the same order as the topic categories above):

1. Trained emergency physicians can effectively and safely provide critical care and perform selected invasive procedures.

2. EM and care rendered in EDs offer many efficiencies and cost-effectiveness of care delivery within the broader healthcare system.

3. EM and EDs can provide a number of effective Public Health and Preventive Medicine measures.

4. Trained EM physicians can accurately and safely interpret radiographic studies.

5. Trained EM physicians can safely and effectively manage trauma patients and perform advanced airway management.

6. Trained EM physicians can safely and accurately perform and interpret ultrasound studies, both diagnostic and procedure-related.

7. EM faculty can deliver high-quality patient care and medical training, and are effective for patient safety.

8. Trained EM physicians can accurately interpret electrocardiograms.

9. EM residency training results in improved patient care in the ED.

10. EM is an important key component for all national healthcare systems.

The article contents and specific article conclusions found in this medical literature review and compilation provide literature-based support for the efficacy of EM and trained emergency physicians. We found that when EM is a distinct and recognized medical specialty with its own specialist training programs (residencies), there is supportive literature for the premise that EM contributes to effective, safe, efficient, and cost-effective patient care.

Limitations of this manuscript include the subjective method used for selection of articles, the subjective consideration of what "value" is, and that an electronic keyword article search was not performed. The authors had determined that as a practical matter this approach was required since using an electronic keyword search with the terms "Emergency Medicine" plus "Efficiency" or "Effectiveness" to identify relevant articles would have missed many of the articles that were identified, since many did not have the terms "efficacy" or "effectiveness" in their titles. A demonstration of the validity of this concern is the manuscript published in 2006 by Peter Hallas [286], which used a structured PubMed search and found only 25 articles on EM efficacy. His article's conclusions were similar to the ones listed above, and included "Having specialists in EM improved care for patients who need urgent treatment..." and "The establishment of a specialty in Emergency Medicine would most likely improve the standard of care for acutely ill patients." 
Another limitation of the current manuscript is that only a limited number of journals were reviewed. So it certainly is likely that there are other relevant articles that demonstrate EM efficacy and effectiveness in other journals that were not reviewed. That such a large number of relevant articles were discovered in spite of this indicates that there may be many more articles in other or earlier journals that support the efficacy and effectiveness of EM, further strengthening the ten conclusion statements above. In addition, since each article was placed into only one category even though a number of the articles actually showed EM efficacy or effectiveness in more than one category, the number of supportive articles in most categories could be considered actually to be higher than the numbers shown in the Results section above.

Since the scientific quality or rigor of the articles included is variable, a strength of evidence analysis of all the included articles would be desirable as well, and should be the focus of future efforts, as should a review of the journals not included in this study. A follow-up goal of this project is to obtain permission from the journals from which the articles were selected to be able to disseminate full text versions of all of the articles as a resource maintained in conjunction with the International Federation for Emergency Medicine.

The authors want to emphasize that this study should be regarded as a preliminary and partial compilation of supportive literature in view of the above-noted study limitations. Also the authors readily acknowledge that, while they encountered only three negative studies compared to the hundreds of positive studies, the methodology was specifically designed to identify and collect articles that were positive toward EM, making the conclusions somewhat preordained.

\section{Conclusions}

There is extensive medical literature support for the efficacy, effectiveness, or value for both EM as a medical specialty and for emergency patient care delivered by trained EM physicians.

\section{Acknowledgements}

No grants were used for this study.

\footnotetext{
Author details

${ }^{1}$ The Center for Disaster and Humanitarian Assistance Medicine, Uniformed Services University of the Health Sciences, and George Washington University School of Medicine and Health Sciences, Bethesda, MD, USA ${ }^{2}$ The Department of Emergency Medicine, University of Maryland School of Medicine, Baltimore, MD, USA, and The Division of Emergency Medicine, Stellenbosch University, Capetown, South Africa ${ }^{3}$ The Department of Military and Emergency Medicine, Uniformed Services University of the Health Sciences, Bethesda, MD, USA, and the Division of Emergency Medicine, University of Texas Southwestern, Dallas, TX, USA ${ }^{4}$ The Department of Emergency Medicine, the Alfred Hospital, Monash University, Melbourne, Australia ${ }^{5}$ The Division of Emergency Medicine, Stellenbosch University,
}

Capetown, South Africa ${ }^{6}$ The Department of Emergency Medicine, Beth Israel Deaconess Medical Center and the Harvard Medical School, Boston, MA, USA ${ }^{7}$ The Department of Emergency Medicine, Loma Linda University, Loma Linda, CA, USA

\section{Competing interests}

The authors declare that they have no competing interests.

Received: 11 February 2011 Accepted: 22 July 2011

Published: 22 July 2011

\section{References}

1. Anderson P, Hegedus A, Ohlen G, Holliman CJ, Williams D, Suter R: Worldwide growth of Emergency Medicine as a recognized medical specialty. Acad Emerg Med 2011, 18(5):S22-S23, (abstract).

2. Mathers CD, Loncar D: Updated projections of global mortality and burden of disease, 2002-2030: data sources, methods and results. World Health Organization Report Geneva, Switzerland; 2006, 237.

3. Anderson P, Petrino R, Halpern P, Tintinalli J: The globalization of emergency medicine and its importance for public health. Bull World Health Org 2006, 84(10):835-839.

4. Jacoby JL, Cesta M, Heller MB, Salen P, Reed J: Synchronized emergency department cardioversion of atrial dysrhythmias saves time, money, and resources. J Emerg Med 2005, 28:27-30.

5. Nguyen HB, Rivers EP, Havstad S, Knoblich B, Ressler J, Muzzin AM, Tomlanovich MC: Critical care in the emergency department: a physiologic assessment and outcome evaluation. Acad Emerg Med 2000, 7:1354-1361.

6. Nelson M, Waldrop RD, Jones J, Randall Z: Critical care provided in an urban emergency department. Am J Emerg Med 1998, 16:56-59.

7. Shoemaker WC, Wo CJ, Bishop MH, Thangathurai D, Patil RS: Noninvasive hemodynamic monitoring of critical patients in the emergency department. Acad Emerg Med 1996, 3:675-681.

8. Brady WJ, Perron AD, Chan T: Electrocardiographic ST-segment elevation: correct identification of acute myocardial infarction (AMI) and non-AMI syndromes by emergency physicians. Acad Emerg Med 2001, 8:349-360.

9. Orebaugh S: Initiation of mechanical ventilation in the emergency department. Am J Emerg Med 1996, 14:59-69.

10. Green SM, Rothrock SG, Harris T, Hopkins GA, Garrett W, Sherwin T: Intravenous ketamine for pediatric sedation in the emergency department: safety profile with 156 cases. Acad Emerg Med 1998, 5:971-976.

11. Steele R, Irvin CB: Central line mechanical complication rate in emergency medicine patients. Acad Emerg Med 2001, 8:204-207.

12. Svenson J, Besinger B, Stapczynski B: Critical care of medical and surgical patients in the ED: length of stay and initiation of intensive care procedures. Am J Emerg Med 1997, 15:654-657.

13. Panacek EA: Intensive care unit care in the emergency department. Acad Emerg Med 1999, 6:675-677.

14. Huizenga J, Zink BJ, Maio RF, Hill EM: Guidelines for the management of severe head injury: are emergency physicians following them? Acad Emerg Med 2002, 9:806-812.

15. Bassett KE, Anderson JL, Pribble CG, Guenther E: Propofol for procedural sedation in children in the emergency department. Ann Emerg Med 2003, 42:773-782.

16. Hayden SR, Panacek E: Procedural competency in emergency medicine: the current range of resident experience. Acad Emerg Med 1999, 6:728-735.

17. Mayglothling JA, Gunnerson KJ, Huang DT: Current practice demographics and trends of critical care trained emergency physicians in the united states. Acad Emerg Med 2010, 17:325-329.

18. Green SM, Baruch K: Propofol in emergency medicine: pushing the sedation frontier. Ann Emerg Med 2003, 42:792-797.

19. Elisabeth G, Pribble CG, Junkins E, Kadish H, Bassett K, Nelson D: Propofol sedation by emergency physicians for elective pediatric outpatient procedures. Ann Emerg Med 2003, 42:783-791.

20. Michelson EA, Brady WJ: Emergency physician interpretation of the electrocardiogram. Acad Emerg Med 2002, 9:317-319.

21. Milzman DP, Rubin S, Moskowitz L: Consideration of adult critical care training for emergency physicians. Acad Emerg Med 1999, 6:345-348. 
22. Birkhahn R, Gaeta T, Tloczkowski J, Mundy T, Sharma M, Bove J, Briggs W: Emergency medicine-trained physicians are proficient in the insertion of transvenous pacemakers. Ann Emerg Med 2004, 43:469-474.

23. Huang D, Osborn T, Gunnerson K, Gunn S, Trzeciak S: Critical care medicine training and certification for emergency physicians. Ann Emerg Med 2005, 46:217-223.

24. Overton DT: Emergency medicine and critical care medicine: have the stars (finally) aligned? Ann Emerg Med 2005, 46:225-227.

25. Berger E: Emergency physicians' voice in the ACLS protocol: guideline's eclectic committee should serve as model. Ann Emerg Med 2006, 47:457-460.

26. Smith M: Thrombolytic therapy for myocardial infarction: pivotal role for emergency medicine. Ann Emerg Med 1987, 16:126-127.

27. Sanders A, Berg R, Burress M, Genova R: The efficacy of an ACLS training program for resuscitation from cardiac arrest in a rural community. Ann Emerg Med 1994, 23:56-59.

28. Kraft P, Newman S, Hanson D, Anderson W, Bastani A: Emergency physician discretion to activate the cardiac catheterization team decreases door-to-balloon time for acute ST-elevation myocardial infarction. Ann Emerg Med 2007, 50:521-526.

29. Kohn M, Kwan E, Gupta M, Tabas J: Prevalence of acute myocardial infarction and other serious diagnoses in patients presenting to an urban emergency department with chest pain. J Emerg Med 2005, 29:383-390.

30. Dire DJ, Kietzman L: A prospective survey of procedures performed by emergency medicine residents during a 36-month residency. J Emerg Med 1995, 13:831-837.

31. Langdorf M, Montague BJ, Bearie B, Sobel C: Quantification of procedures and resuscitations in an emergency medicine residency. $J$ Emerg Med 1998, 16:121-127.

32. Miner J, Heegaard W, Mapes A, Biros M: Presentation time to antibiotics and mortality of patients with bacterial meningitis at an urban county medical center. J Emerg Med 2001, 21:387-392.

33. Magid D, Bradley E: Emergency physician activation of the cath lab: saving time saving lives. Ann Emerg Med 2007, 50:535-537.

34. Barroso B, Morisset C, Larrieu J, Bertandeau E, Dakar A, Mangon H, Rouanet F: Stroke thrombolysis in the emergency department as an alternative service for community hospitals lacking a stroke unit. Eur J Emerg Med 2008, 15:71-74.

35. Williams RM: The costs of visits to emergency departments. New Eng J Med 1996, 334:642-646.

36. Hampers LC, Cha S, Gutglass DJ, Binns Helen JB, Krug SE: Fast track and the pediatric emergency department: resource utilization and patient outcomes. Acad Emerg Med 1999, 6:1153-1159.

37. Simon HK, McLario D, Daily R, Lanese C, Castillo J, Wright J: "Fast tracking" patients in an urban pediatric emergency department. Am J Emerg Med 1996, 14:242-244.

38. Simon HK, Ledbetter DA BIE, Wright J: Societal savings by "Fast Tracking" lower acuity patients in an urban pediatric emergency department. Am J Emerg Med 1997, 15:551-554.

39. Lateef F, Anantharaman V: The short-stay emergency observation ward is here to stay. Amer J Emerg Med 2000, 18:629-634.

40. Patel $S$, Dubinsky I: Outcomes of referrals to the ED by family physicians. Am J Emerg Med 2002, 20:144-150.

41. Sacchetti A, Harris RH, Warden T, Roth S: Contribution of ED admissions to inpatient hospital revenue. Am J Emerg Med 2002, 20:30-31.

42. Hauswald M: The ED is an efficient place to treat ED patients. Am J Emerg Med 2004, 22:564-567.

43. Jagminas $L$, Partridge $R$ : A comparison of emergency department versus inhospital chest pain observation units. Am J Emerg Med 2005, 23:111-113.

44. Northington WE, Brice JH: Use of an emergency department By nonurgent patients. Amer J Emerg Med 2005, 23:131-137.

45. Chen EH, Shofer FS, Hollander JE, Robey JL, Sease KL, Mills AM: Emergency physicians do not use more resources to evaluate Obese Patients with Acute Abdominal Pain. Am J Emerg Med 2007, 25:925-930.

46. Haukoos JS, Witt MD, Leiws RJ: Derivation and reliability of an instrument to estimate medical benefit of emergency treatment. Am J Emerg Med 2010, 28:404-411.

47. Storrow $A B$, Gibler WB: Chest pain centers: diagnosis of acute coronary syndromes. Ann Emerg Med 2000, 35:449-461.
48. Vinson DR, Berman DA: Outpatient treatment of deep venous thrombosis: a clinical care pathway managed by the emergency department. Ann Emerg Med 2001, 37:251-258.

49. Koenig BO, Ross MA, Jackson RE: An emergency department observation unit protocol for acute-onset fibrillation is feasible. Ann Emerg Med 2002, 39:374-381.

50. Ross MA, Compton S, Richardson D, Jones R, Nittis T, Wilson A: The use and effectiveness of an emergency department observation unit for elderly patients. Ann Emerg Med 2003, 41:668-677.

51. McCusker J, Jacobs P, Dendukuri N, Latimer E, Tousignant P, Verdon J: Costeffectiveness of a brief two-stage emergency department intervention for high-risk elders: results of a quasi-randomized controlled trial. Ann Emerg Med 2003, 41:45-56.

52. William R: The costs of visits to emergency departments -revisited. Ann Emerg Med 2005, 46:471-472.

53. Singer AJ, Camargo CA, Lampell M, Lewis L, Nowak R, Schafermeyer RW O'Neil BA: Call for expanding the role of emergency physician in the care of patients with asthma. Ann Emerg Med 2005, 45:295-298.

54. Magid D, Bradley E: Emergency physician activation of the cath lab: saving time saving lives. Ann Emerg Med 2007, 50:535-537.

55. Singer AJ, Shembekar A, Visram F, Russo V, Lawson W, Gomes C, Santora C, Mallszewski M, Wilbert L, Dowdy E, Vicceillo P, Henry MC: Emergency department activation of an interventional cardiology team reduces door-to-balloon times in ST-segment-elevation myocardial infarction. Ann Emerg Med 2007, 50:538-544.

56. Decker WW, Smars PA, Valdyanathan L, Goyal D, Bole E, Packer D, Meloy TD Boggust AJ, Haro LH, Laudon DA, Lobi JK, Saodsty AT, Schears RM, Schlebel NE, Hodge DO, Shen W: A prospective randomized trial of an emergency department observation unit for acute onset atrial fibrillation. Ann Emerg Med 2008, 52:322-328.

57. Handel DA, McConnell KJ, Wallace N, Galla C: How much does emergency department use affect the cost of medicaid programs. Ann Emerg Med 2008, 51:614-621.

58. Henneman PL, Lemanski M, Smithline HA, Tomaszewski A, Mayforth JA: Emergency department admissions are more profitable than nonemergency department admissions. Ann Emerg Med 2009, 53:249-255.

59. Quick G: Time analysis of consult service emergency department admission process compared with emergency medicine service admission process. J Emerg Med 1999, 17:815-822.

60. Platz E, Bey T, Walter F: International report: current state and development of health insurance and emergency medicine in Germany: the influence of health insurance laws on the practice of emergency medicine in a European country. J Emerg Med 2003, 25:203-210.

61. Sanchez M, Smally A, Grant RJ, Jacobs LM: Effects of a fast-track area on emergency department performance. J Emerg Med 2006, 31:117-120.

62. Pines JM: The economic role of the emergency department in the health care continuum: applying Michael Porter's five forces model to emergency medicine. J Emerg Med 2006, 30:447-453.

63. Travers JP, Lee FCY: Avoiding prolonged waiting time during busy periods in the emergency department: is there a role for the senior emergency physician in triage? Eur J Emerg Med 2006, 13:342-348.

64. Roberts MV, Baird W, Kerr P, O'Reilly S: Can an emergency departmentbased clinical decision unit successfully utilize alternatives to emergency hospitalization? Eur J Emerg Med 2010, 17:89-96.

65. James T, Aschkenasy M, Eliseo L, Olshaker J, Mehta S: Response to hepatitis a epidemic: emergency department collaboration with public health commission. J Emerg Med 2009, 36:412-416.

66. Wrenn K, Rice N: Social-work services in an emergency department: an integral part of the health care safety net. Acad Emerg Med 1994, 247-253.

67. Bernstein E, Goldfrank L, Kellerman A, Hargarten S, Jui J, Fish S, Herbert B, Flores C, Caravati M, Krishel S, Stevens C, Kirsch T, Lowe R, Lowenstein S, Baraff L, Mueller-Orsay E, Ling L, Sklar D: A public health approach to emergency medicine: preparing for the twenty-first century. Acad Emerg Med 1994, 1:277-286.

68. Ernst A, Farley T, Martin D: Screening and empiric treatment for syphilis in an inner-city emergency department. Acad Emerg Med 1995, 2:765-762.

69. Waxweiler R: The role of the emergency department in creating a safe America. Acad Emerg Med 1997, 4:761-763.

70. D'Onofrio G, Bernstein E, Bernstein J, Woolard R, Brewer P, Craig S, Zink B: Patients with alcohol problems in the emergency department, part 2: intervention and referral. Acad Emerg Med 1998, 5:1210-1217. 
71. Gordon J, Goldfrank L, Andrulis D, D'Alessandri R, Kellermann A: Emergency department initiatives to improve the public health. Acad Emerg Med 1998, 5:935-937

72. Kirsch T, Chanmugam A, Keyl P, Regan L, Shahan J, Hexter D, Kelen G: Feasiblity of an emergency department-based tuberculosis counseling and screening program. Acad Emerg Med 1999, 6:224-231.

73. Wei $\mathrm{H}$, Camargo C Jr: Patient education in the emergency department. Acad Emerg Med 2000, 7:710-717.

74. Weigand J, Gerson L: Preventive care in the emergency department should emergency departments institute a falls prevention program for elder patients? A systematic review. Acad Emerg Med 2001, 8:823-826.

75. Gordan J: Cost-benefit analysis of social work services in the emergency department: a conceptual model. Acad Emerg Med 2001, 8:54-60.

76. Bernstein S, Becker B: Preventive care in the emergency department: diagnosis and management of smoking and smoking-related illness in the emergency department: a systemic review. Acad Emerg Med 2002, 9:720-729

77. D'Onofrio G, Degutis L: Preventive care in the emergency department: screening and brief intervention for alcohol problems in the emergency department: a systemic review. Acad Emerg Med 2002, 9:627-638.

78. McCloskey L, Lichter E, Ganz M, Williams C, Gerber M, Sege R, Stair T, Herbert B: Intimate partner violence and patient screening across medical specialties. Acad Emerg Med 2005, 12:712-722.

79. Rimple D, Weiss S, Brett M, Ernst A: An emergency department-based vaccination program: overcoming the barriers for adults at high risk for vaccine-preventable diseases. Acad Emerg Med 2006, 13:922-930.

80. Bernstein SL, Haukoos JS: Public health, prevention, and emergency medicine: a critical juxtaposition. Acad Emerg Med 2008, 15:190-193.

81. Vaca FE, Sayegh R, Mello MJ, Hargarten SW: Historical parallel evolution of injury prevention and control science and emergency medicine. Acad Emerg Med 2009, 16:1049-1053.

82. Kellermann A: Emergency medicine and public health: stopping emergencies before the 9-1-1 call. Acad Emerg Med 2009, 16:1060-1064.

83. Kelso T, Self T, Rumbak M, Stephens M, Garrett W, Arheart K: Educational and long-term therapeutic intervention in the ED: effect on outcomes in adult Indigent minority asthmatics. Amer J Emerg Med 1995, 13:632-637.

84. Iserson K, Kastre T: Are emergency departments really a "safety net" for the medically indigent? Amer J Emerg Med 1996, 14:1-5.

85. Bernstein E, Bernstein J, Levenson S: Project ASSERT: an ED-based intervention to increase access to primary care, preventive services, and the substance abuse treatment system. Ann Emerg Med 1997, 30:181-189.

86. Gordon J: The hospital emergency department as a social welfare institution. Ann Emerg Med 1999, 33:321-325.

87. Pollack D, Lowery D, O'Brien P: Emergency medicine and public health: new steps in old directions. Ann Emerg Med 2001, 39:675-683.

88. Mace S, Geradi M, Dietrich A, Knazik S, Mulligan-Smith D, Sweeney R, Warden C: Injury prevention and control in children. Ann Emerg Med 2001, 39:405-414.

89. McCammon K: Alcohol-related motor vehicle crashes: deterrence and intervention. Ann Emerg Med 2001, 39:415-422.

90. Krasnoff M, Moscati R: Domestic violence screening and referral can be effective. Ann Emerg Med 2002, 40:485-492.

91. Mion L, Palmer R, Meldon S, Bass D, Singer M, Payne S, Lewicki L, Drew B, Connor J, Campbell J, Emerman C: Case finding and referral model for emergency department elders: a randomized clinical trial. Ann Emerg Med 2003, 41:57-68.

92. Gordon J: The science of common sense: integrating health and human services in the hospital emergency department. Ann Emerg Med 2005, 45:251-252.

93. Mahajan P, Stanley R, Ross K, Clark L, Sandberg K, Lichtenstein R: Evaluation of an emergency department-based enrollment program for uninsured children. Ann Emerg Med 2005, 45:245-250.

94. Bernstein S, Boudreaux E, Cydulka R, Rhodes K, Lettman N, Almeida S, McCullough L, Mizouni S, Kellermann A: Tobacco control interventions in the emergency department: a joint statement of emergency medicine organizations. Ann Emerg Med 2006, 48:e417-e425.

95. Bernstein E, Bernstein J: Effectiveness of alcohol screening and brief motivational intervention in the emergency department setting. Ann Emerg Med 2008, 51:751-754.
96. D'Onofrio G, Pantalon M, Degutis L, Flellin D, Busch S, Chawarski M, Owens $P, O^{\prime}$ Connor P: Brief intervention for hazardous and harmful drinkers in the emergency department. Ann Emerg Med 2008, 51:742-750.

97. Carpenter C: Preventing falls in community-dwelling older adults. Ann Emerg Med 2010, 55:296-298.

98. Waxman M, Muganda P, Carter E, Ongaro N: The role of emergency department HIV care in resource-poor settings: lessons learned In western kenya. Intl J Emerg Med 2008, 1:317-320.

99. Lufkin KC, Smith SW, Matticks CA, Brunette DD: Radiologists' review of radiographs interpreted confidently by emergency physicians infrequently leads to changes in patient management. Ann Emerg Med 1998, 31:202-207.

100. Ilkhanipour K, Seaberg DC: Radiographic interpretation by emergency medicine residents. Acad Emerg Med 1995, 2:1113-1114.

101. Minnes BG, Sutcliffe T, Klassen TP: Agreement in the interpretation of extremity radiographs of injured children and adolescents. Acad Emerg Med 1995, 2:826-830

102. Nitowski LA, O'Connor RE, Reese CL: The rate of clinically significant plain radiograph misinterpretation by faculty in an emergency medicine residency program. Acad Emerg Med 1996, 3:782-789.

103. Brunswick JE, Ilkhanipour K, Fuchs S, Seaberg D: Emergency medicine resident interpretation of pediatric radiographs. Acad Emerg Med 1996, 3:790-793

104. Holdgate A, Chan T: How accurate are emergency clinicians at interpreting noncontrast computed tomography for suspected renal colic. Acad Emerg Med 2003, 10:315-319.

105. Gouin S, Patel H, Bergeron S, Amre D, Guerin R: The effect of picture archiving and communications systems on the accuracy of diagnostic interpretation of Pediatric Emergency Physicians. Acad Emerg Med 2006, 13:186-190.

106. Brunswick JE, Ilkhanipour K, Seaberg DC, McGill L: Radiographic interpretation in the emergency department. Am J of Emerg Med 1996, 14:346-348.

107. Simon HK, Khan NS, Nordenberg DF, Wright JA: Pediatric emergency physician interpretation of plain radiographs: is routine review by a radiologist necessary and cost-effective? Ann Emerg Med 1996, 27:295-298.

108. Levitt MA, Dawkins R, Williams V, Bullock S: Abbreviated educational session improves cranial computed tomography scan interpretations by emergency physicians. Ann Emerg Med 1997, 30:616-621.

109. Al-Reesi A, Stiell IG, Al-Zadjali N, Cwinn AA: Comparison of CT head interpretation between emergency physicians and neuroradiologists. Eur J Emerg Med 2010, 17:280-282.

110. Sakles JC, Deacon JM, Bair AE, Keim SM, Panacek EA: Delayed complications of emergency airway management: a study of 533 emergency department intubations. Western J Emerg Med 2008, 11:190-194.

111. Hartmann J, Gabram S, Jacobs L, Libby M: A model for an integrated emergency medicine/trauma service. Acad Emerg Med 1996, 3:1136-1139.

112. Chang RS, Hamilton RJ, Carter WA: Declining rate of cricothyrotomy in trauma patients with an emergency medicine residency: implications for skills training. Acad Emerg Med 1998, 5:247-251.

113. Bozeman WP, Gaasch WR, Barish RA, Scalea TM: Trauma resuscitation/ critical care fellowship for emergency physicians: a necessary step for the future of academic emergency medicine. Acad Emerg Med 1999, 6:331-333.

114. Tayal VS, Riggs RW, Marx JA, Tomaszewski CA, Schneider RE: Rapidsequence intubation at an emergency medicine residency: success rate and adverse events during a two-year period. Acad Emerg Med 1999, 6:31-37.

115. Bushra JS, McNeil B, Wald DA, Schwell A, Karras DJ: A comparison of trauma intubations managed by anesthesiologists and emergency physicians. Acad Emerg Med 2004, 11:66-70.

116. Ma JO, Bently B, Debehnke DJ: Airway management practices in emergency medicine residencies. Am J Emerg Med 1995, 13:501-504.

117. Leslie CL, Cushman M, McDonald GS, Joshi W, Maynard AM: Management of multiple burn casualties in a high volume ED without a verified burn unit. Am J Emerg Med 2001, 19:469-473.

118. Germann CA, Geyer DA, Perron AD: Closed reduction of prosthetic hip dislocation by emergency physicians. Am J Emerg Med 2005, 23:800-805. 
119. Plaisier BR, Meldon SW, Super DM, Jouriles NJ, Barnoski AL, Fallon WF, Malangoni MA: Effectiveness of a 2-speciality 2-tiered triage and trauma team activation protocol. Ann Emerg Med 1998, 32:436-441.

120. Sakles JC, Laurin EG, Rantapaa AA, Panacek EA: Airway management in the emergency department: a one-year study of 610 tracheal intubations. Ann Emerg Med 1998, 31:324-332

121. Green SM, Rothrock SG: Is pediatric trauma really a surgical disease? Ann Emerg Med 2002, 39:537-540.

122. Levitan RM, Rosenblatt B, Meiner EM, Reilly PM, Hollander JE: Alternating day emergency medicine and anesthesia resident responsibility for management of the trauma airway: a study of laryngoscopy performance and intubation success. Ann Emerg Med 2004, 43:48-53.

123. Sagarin MJ, Barton ED, Ching Y, Walls RM: Airway management by US and Canadian emergency medicine residents: a multicenter analysis of more than 6000 endotracheal intubation attempts. Ann Emerg Med 2005, 46:328-336.

124. Green SM: Is there evidence to support the need for routine surgeon presence on trauma patient arrival? Ann Emerg Med 2006, 47:405-411.

125. Ahmed JM, Tallon JM, Petrle DA: Trauma management outcomes associated with nonsurgeon versus surgeon trauma team leaders. Ann Emerg Med 2007, 50:7-12

126. Millard WB: A fine excision: ATLS manual no longer defines trauma as a surgical disease. Ann Emerg Med 2010, 55:19-24.

127. Green SM: Trauma surgery: discipline in crisis. Ann Emerg Med 2009, 53:198-207.

128. Wong $\mathrm{E}_{\mathrm{A}} \mathrm{Ng} \mathrm{Y}$ : The difficult airway in the emergency department. Int J Emerg Med 2008, 1:107-111.

129. Reeder TJ, Brown CK, Norris DL: Managing the Difficult airway: a survey of residency directors and a call for change. J Emerg Med 2005, 28:473-478.

130. Singer AJ, Singer AH, Halperin P, Kaspi G, Assaf J: Medical lessons from terror attacks in Israel. J Emerg Med 2007, 32:87-92.

131. Gildea JR, Janssen AR: Tactical emergency medical support: physical involvement and injury patterns in tactical teams. J Emerg Med 2008, 35:411-414.

132. Pershad J, Williams S, Wan J, Sawyer J: Pediatric distal radial fractures treated by emergency physicians. J Emerg Med 2009, 37:341-344.

133. Henderson SO, McClung CD, Sintu C, Swadron SP: The presence of an emergency airway response team and its effects on in-hospital code blue. J Emerg Med 2009, 36:116-120.

134. Squyer E, Cherry RA, Lehman E, Yanturali S, Kilicaslan I, Oktay C, Holliman CJ: Comparison of trauma mortality between two hospitals in Turkey to one trauma center in the US. Eur J Emerg Med 2008, 15:209-213.

135. Boyle AA, Atkinson PRT, Ahmed V, Kark WWT: Emergency physician performed rapid sequence induction and system changes reduce time to intubation in critically ill emergency medicine patients. Eur J Emerg Med 2008, 15:243-244.

136. Dufour DG, Larose DL, Clement SC: Rapid sequence intubation in the emergency department. J Emerg Med 1995, 13:705-710.

137. Jang T, Docherty M, Aubin C, Polites G: Resident-performed compression ultrasonography for the detection of proximal deep vein thrombosis: fast and accurate. Acad Emerg Med 2004, 1:319-322.

138. Mateer J, Aiman JEB, Brown M, Olson D: Ultrasonographic examination by emergency physicians of patients at risk for ectopic pregnancy. Acad Emerg Med 1995, 2:867-873.

139. Ingeman J, Plewa M, Okasinski R, King R, Knotts FB: Emergency physician use of ultrasonography in blunt abdominal trauma. Acad Emerg Med 1996, 3:931-937

140. Jolly T, Massarin E, Pigman C: Color Doppler ultrasonography by emergency physicians for the diagnosis of acute deep venous thrombosis. Acad Emerg Med 1997, 4:129-132.

141. Burgher S, Tandy T, Dawdy M: Transvaginal ultrasonography by emergency physicians decreases patient time in the emergency department. Acad Emerg Med 1998, 5:802-817.

142. Henderson S, Hoffner R, Aragona J, Groth D, Esekogwu V, Chan D: Beside emergency department ultrasonography plus radiography of the kidneys, ureters, and bladder vs intravenous pyelography in the evaluation of suspected ureteral colic. Acad Emerg Med 1998, 5:666-671.

143. Lanoix R, Baker W, Mele J, Dharmarajan L: Evaluation of an instructional model for emergency ultrasonography. Acad Emerg Med 1998, 5:58-63.
144. Blaivas M, Harwood R, Lambert M: Decreasing length of stay with emergency ultrasound examination of the gallbladder. Acad Emerg Med 1999, 6:1020-1023.

145. Blaivas M, Lambert M, Harwood R, Wood J, Konicki J: Lower-extremity Doppler for deep venous thrombosis-can emergency physicians be accurate and fast? Acad Emerg Med 2000, 7:120-126.

146. Salen P, Melanson S, Heller M: The focused abdominal sonography for trauma (fast) examination: considerations and recommendations for training physicians in the use of a new clinical tool. Acad Emerg Med 2000, 7:162-168.

147. Rodgerson J, Heegaard W, Plummer D, Hicks J, Clinton J, Sterner S: Emergency department right upper quadrant ultrasound is associated with a reduced time to diagnosis and treatment of ruptured ectopic pregnancies. Acad Emerg Med 2001, 8:331-336.

148. Blaivas M, Sierzenski $P$, Lambert M: Emergency evaluation of patients presenting with acute scrotum using bedside ultrasonography. Acad Emerg Med 2001, 8:90-93.

149. Heller M, Mandavia D, Tayal V, Cardenas E, Lambert M, Mateer J, Melanson S, Peimann N, Plummer D, Stahmer S: Residency training in emergency ultrasound: fulfilling the mandate. Acad Emerg Med 2002, 9:835-839

150. Moore C, Rose G, Tayal V, Sullivan M, Arrowood J, Kline J: Determination of left ventricular function by emergency physician echocardiography of hypotensive patients. Acad Emerg Med 2002, 9:186-193.

151. Tayal V, Graf C, Gibbs M: Prospective study of accuracy and outcome of emergency ultrasound for abdominal aortic aneurysm over two years. Acad Emerg Med 2003, 10:867-871.

152. Counselman F, Sanders A, Slovis C, Danzl D, Binder L, Perina D: The status of bedside ultrasonography training in emergency medicine residency programs. Acad Emerg Med 2003, 10:37-42.

153. Brannam L, Blaivas M, Lyon M, Flake M: Emergency nurses' utilization of ultrasound guidance for placement of peripheral intravenous lines in difficult-access patients. Acad Med 2004, 11:1361-1363.

154. Plummer D: Whose turf is it, anyway? Diagnostic ultrasonography in the emergency department. Acad Emerg Med 2000, 7(2):186-187.

155. Durham B: Emergency medicine physicians saving time with ultrasound. Am J Emerg Med 1996, 14:309-313.

156. Gaspari R, Horst K: Emergency ultrasound and urinalysis in the evaluation of flank pain. Acad Emerg Med 2005, 12:1180-1184.

157. Witt M, Baumann B, McCans K: Bladder ultrasound increases catheterization success in pediatric patients. Acad Emerg Med 2005, 12:371-374.

158. Tayal VS, Hasan N, Norton J, Tomaszewski CA: The effect of soft-tissue ultrasound on the management of cellulitis in the emergency department. Acad Emerg Med 2006, 13:384-388.

159. Cook T, Hunt P, Hoppman R: Ultrasound is a necessary skill for emergency physicians. Acad Emerg Med 2006, 13:334-336

160. Cook T, Hunt P, Hoppman R: Emergency medicine leads the way for training medical students in clinician-based ultrasound: $A$ radical paradigm shift in patient imaging. Acad Emerg Med 2007, 14:558-561.

161. Burnside PR, Brown MD, Kline J: Systematic review of emergency physician-performed ultrasonography for lower-extremity deep vein thrombosis. Acad Emerg Med 2008, 15:493-498.

162. Soremekun OA, Noble VE, Liteplo A, Brown DF, Zane RD: Financial impact of emergency department ultrasound. Acad Emerg Med 2009, 16:674-680.

163. Sankoff J, Keyes LE: Emergency medicine resident education: making a case for training residents to perform and interpret bedside sonographic examinations. Ann Emerg Med 1999, 34:105-108.

164. Durston W, Carl ML, Guerra W: Patient satisfaction and diagnostic accuracy with ultrasound by emergency physicians. Am J Emerg Med 1999, 17:643-646.

165. Lanoix R, Leak LV, Gaeta T, Gernsheimer JR: A preliminary evaluation of emergency ultrasound in the setting of an emergency medicine training program. Am J Emerg Med 2000, 18:41-45.

166. Adhikari S, Blaivas M, Lyon M: Diagnosis and management of ectopic pregnancy using bedside transvaginal ultrasonography in the ED: a 2year experience. Am J Emerg Med 2007, 25:591-600.

167. Olson D: Ultrasound in emergency medicine. Ann Emerg Med 1996, $28: 113$. 
168. Mateer JR, Valley VT, Aiman JE, Phelan MB, Thoma ME, Kefer MP: Outcome analysis of a protocol including bedside endovaginal sonography in patients at risk for ectopic pregnancy. Ann Emerg Med 1996, 27:283-289.

169. Durham B, Lane B, Burbridge L: Pelvic ultrasound performed by emergency physicians for the detection of ectopic pregnancy in complicated first-trimester pregnancies. Ann Emerg Med 1997, 29:338-347.

170. Shih $\mathrm{CH}$ : Effect of emergency physician-performed pelvic sonography on length of stay in the emergency department. Ann Emerg Med 1997, 29:348-352.

171. Nordenholz KE, Rubin MA, Gularte GG, Liang HK: Ultrasound in the evaluation and management of blunt abdominal trauma. Ann Emerg Med 1997, 29:357-366.

172. Tandy TK, Hoffenberg S: Emergency department ultrasound services by emergency physicians: model for gaining hospital approval. Ann Emerg Med 1997, 29:367-374.

173. Scruggs W, Fox J, Potts B, Zlidenny Alexander McDonough J, Anderson C, Larson J, Barajas G, Langdorf M: Accuracy of ED bedside ultrasound for identification of gallstones: retrospective analysis of 575 studies. Western J Emerg Med 2008, 9:1-5.

174. Kuhn M, Bonnin R, Davey M, Rowland J, Langlois S: Emergency department ultrasound scanning for abdominal aortic aneurysm: accessible, accurate, and advantageous. Ann Emerg Med 2000, 36:219-223.

175. Mandavia D, Hoffner R, Mahaney K, Henderson S: Bedside echocardiography by emergency physicians. Ann Emerg Med 2001, 38:377-382.

176. Kline J, O'Malley P, Tayal V, Snead G, Mitchell A: Emergency clinicianperformed compression ultrasonography for deep venous thrombosis of the lower extremity. Ann Emerg Med 2008, 52:437-445.

177. Blackstock U, Stone M: Emergency ultrasonography and error reduction. Ann Emerg Med 2009, 54:53-55.

178. Jain A, Stead L, Decker W: Ultrasound in emergency medicine: a colorful future in black and white. Intl J Emerg Med 2008, 1:251-252.

179. Tsui C, Fung H, Chung K, Kam C: Focused abdominal sonography for trauma in the emergency department for blunt abdominal trauma. Int/ J Emerg Med 2008, 1:183-187.

180. Shah S, Noble V, Umulisa I, Dushimiyimana J, Bukhman G, Mukherjee J, Rich $M$, Epino $H$ : Development of an ultrasound training curriculum in a limited resource international setting: successes and challenges of ultrasound training in rural Rwanda. Int/ J Emerg Med 2008, 1:193-196.

181. Rosen C, Brown D, Sagarin M, Chang Y, McCabe C, Wolfe R: Ultrasonography by emergency physicians in patients with suspected ureteral colic. J Emerg Med 1998, 16(6):865-870.

182. Kendall J, Shimp R: Performance and interpretation of focused right upper quadrant ultrasound by emergency physicians. J Emerg Med 2001, 21(1):7-13.

183. Bassler D, Snoey E, Kim J: Goal-directed abdominal ultrasonography: impact on real-time decision making in the emergency department. J Emerg Med 2003, 24(4):375-378.

184. Costantino T, Bruno E, Neal H, Dean A: Accuracy of emergency medicine ultrasound in the evaluation of abdominal aortic aneurysm. J Emerg Med 2005, 29(4):455-460.

185. Knaut A, Kendall J, Patten R, Ray C: Ultrasonographic measurement of aortic diameter by emergency physicians approximates results obtained by computed tomography. J Emerg Med 2005, 28(2):119-126.

186. Miller A, Pepe P, Brockman R, Delaney K: ED ultrasound in hepatobiliary disease. J Emerg Med 2006, 30(1):69-74.

187. Jacoby J, Cesta M, Axelband J, Melanson S, Heller M, Reed J: Can emergency medicine residents detect acute deep venous thrombosis with a limited, two-site ultrasound examination? J Emerg Med 2007, 32(2):197-200

188. Dean A, Breyer M, Ku B, Mills A, Pines J: Emergency ultrasound usage among recent emergency medicine residency graduates of a convenience sample of 14 residencies. J Emerg Med 2010, 38(2):214-221.

189. Summers SM, Scruggs W, Menchine MD, Lahham S, Anderson C, Lotfipour S, Cusick SS, Fox JC: A prospective evaluation of emergency department bedside ultrasonography for the detection of acute cholecystitis. Ann Emerg Med 2010, 56:114-122.

190. Unluer EE, Yavasi O, Eroglu O, Yilmaz C, Akarca FK: Ultrasonography by emergency medicine and radiology residents for the diagnosis of small bowel obstruction. Eur J Emerg Med 2010, 17:260-264.
191. Hoyer HX, Vogl S, Schiemann U, Haug A, Stolpe E, Michalski T: Prehospital ultrasound in emergency medicine: incidence, feasibility, indications, and diagnoses. Eur J Emerg Med 2010, 17:254-259.

192. Jorgensen $H$, Jensen $C H$, Dirks J: Does prehospital ultrasound improve treatment of the trauma patient? a systematic review. Eur J Emerg Med 2010, 17:249-253.

193. Weaver CS, Avery SJ, Brizendine EJ, McGrath RB: Impact of emergency medicine faculty on door to thrombolytic time. J Emerg Med 2004, 26:279-283.

194. Hirshberg MD, Holliman CJ, Wuerz RC, Chapman DM: Case Management by Physician Assistants and Primary Care Physicians vs. Emergency Physicians. Acad Emerg Med 1997, 4:1046-1052.

195. Ling $L$, Bowles LT, Reynolds R, Kroot L, Roth P: Emergency medicine in the medical school curriculum. Acad Emerg Med 1997, 4:1070-1077.

196. Jouriles NJ, Kuhn GJ, Moorhead JC, Ray G, Rund DA: Faculty development in emergency medicine. Acad Emerg Med 1997, 4:1078-1086.

197. Veenema KR: The integration of primary care sports medicine into an academic emergency medicine practice: academic and revenue enhancement. Acad Emerg Med 1999, 6:828-831.

198. Buckley RG, Distefan J, Gubler KD, Slymen D: The risk of appendiceal rupture based on hospital admission source. Acad Emerg Med 1999, 6:596-601.

199. Meldon SW, Cydulka RK, Jouriles NJ, Emerman CL: Academic emergency medicine staffing nonacademic emergency department sites: a national survey. Acad Emerg Med 1999, 6:334-338.

200. Tamariz VP, Fuchs S, Baren JM, Pollack ES, Kim J, Seidel J: Pediatric emergency medicine education in emergency medicine training programs. Acad Emerg Med 2000, 7:774-778.

201. Jones JH, Weaver CS, Rusynlak DE, Brizendine EJ, McGrath RB: Impact of emergency medicine faculty and an airway protocol on airway management. Acad Emerg Med 2002, 9:1452-1456.

202. Berger TJ, Ander DS, Terrell M, Berle DC: The impact of the demand for clinical productivity on student teaching in academic emergency departments. Acad Emerg Med 2004, 11:1364-1367.

203. Hohl CM, Robitaille C, Lord V, Dankoff J, Colacone A, Pham L, Berard A, Pepin J, Afilalo M: Emergency physician recognition of adverse drugrelated events in elder patients presenting to an emergency department. Acad Emerg Med 2005, 12:197-205.

204. Kelly SP, Shapiro N, Woodruff M, Corrigan K, Sanchez LD, Wolfe RE: The effects of clinical workload on teaching in the emergency department. Acad Emerg Med 2007, 14:526-531.

205. Youngquist ST, Shah AP, Niemann JT, Kaji AH, French WJ: A comparison of door-to-balloon times and false-positive activations between emergency department and out-of-hospital activation of the coronary catheterization team. Acad Emerg Med 2008, 15:784-787.

206. Kharbanda AB, Fishman SJ, Bachur RG: Comparison of pediatric emergency physicians' and surgeons' evaluation and diagnosis of appendicitis. Acad Emerg Med 2008, 15:119-125.

207. Dorfsman ML, Wolfson AB: Direct observation of residents in the emergency department: a structured educational program. Acad Emerg Med 2009, 16:343-351.

208. Holliman CJ, Wuerz RC, Kimak MJ, Burkhart KK, Donovan JW, Rudnick HL, Bates MA, Muller HA: Attending supervision of nonemergency medicine residents in a university hospital ED. Am J Emerg Med 1995, 13:259-261.

209. Chern C, Tsai J, Wong PS, Hu SC: Rotating residents' impressions of an ED managed by career emergency physicians. Am J Emerg Med 1995, 13:232-235.

210. Hunt RC, DeHart K, Allison EJ, Whitley TW: Patient and physician perception of need for emergency medical care: a prospective and retrospective analysis. Am J Emerg Med 1996, 14:635-639.

211. Brillman JC, Doezema D, Tandberg D, Sklar DP, Skipper BJ: Does a physician visual assessment change triage? Am J Emerg Med 1997 15:29-33.

212. Caterino JM, Holliman CJ, Kunselman AR: Underestimation of case severity by emergency department patients: implications for managed care. Am J Emerg Med 2000, 18:254-256.

213. Seow V, Lin A, Chen C, Chen K, Wang T, Chong C: Comparing different patterns for managing febrile children in the ED between emergency and pediatric physicians: impact on patient outcome. Amer J Emerg Med 2007, 25:1004-1008. 
214. Cutler K, Bush A, Godambe S, Gilmore B: The use of pediatric emergency medicine-staffed sedation service during imaging: a retrospective analysis. Amer J of Emerg Med 2007, 25:655-661.

215. Unterman S, Kessler C, Pitzele Z: Staffing of the ED by non-emergencytrained personnel: the VA experience. Amer J Emerg Med 2010, 28:622-625.

216. Emslander H, Bonadio W, Klatzo M: Efficacy of esophageal bougienage by emergency physicians in pediatric coin ingestion. Ann Emerg Med 1996, 27:726-729.

217. Todd KH, Hoffman JR, Morgan MT: Effect of cardiologist ECG review on emergency department practice. Ann Emerg Med 1996, 27:16-21.

218. Lambrecht CJ: Emergency physicians' roles in a clinical telemedicine network. Ann Emerg Med 1997, 30:670-674.

219. Berger E: Emergency physicians' voice In the ACLS protocol: guidelines eclectic committee should serve as model. Ann Emerg Med 2006, 47:457-460.

220. Kraft P, Newman S, Hanson D, Anderson W, Bastani A: Emergency physician discretion to activate the cardiac catheterization team decreases door-to-baloon time for acute ST-elevation myocardial infarction. Ann Emerg Med 2007, 50:520-526.

221. Berk W, Welch R, Levy P, Jones J, Arthur C, Kuhn GJ, King J, Bock B, Sweeny $P$ : The effect of clinical experience on the error rate of emergency physicians. Ann Emerg Med 2008, 52:497-501.

222. Kroboth F, Brown F, Stewart R, Karpf M, Levey G: Impact of attending level supervision of the emergency department experience. Ann Emerg Med 1982, 11:192-196.

223. Sacchetti A, Carraccio C, Harris R: Resident management of emergency department patients: is closer attending supervision needed? Ann Emerg Med 1992, 21:749-752.

224. Misra S, Mahajan P, Chen X, Kannikeswaran N: Safety of procedural sedation and analgesia in children less than two years of age in a pediatric emergency department. Intl J Emerg Med 2008, 1:173-177.

225. Pitre $\mathrm{CJ}$ : The unique educational value of emergency medicine student interest groups. J Emerg Med 2002, 22:427-428.

226. Deflitch C, Holliman CJ: Medical care errors by mid-level practitioners: is direct emergency physician supervision needed? Ann Emerg Med 2001, 38:547, (abstract).

227. Woolrdige DP, Lichenstein R: A survey on the graduates from the combined emergency medicine/pediatric residency programs. J Emerg Med 2007, 32:137-140.

228. Gallagher JE, Coffey J, Lombardi G, Saef S: Medicine residents: who performs them in the emergency department. Acad Emerg Med 1995, 2:630-633

229. Alagappan K, Steinberg M, Mancherje N, Pollack S, Carpenter K: The psychological effects of a four-week emergency medicine rotation on residents in training. Acad Emerg Med 1996, 3:1131-1135.

230. Singer AJ, Hollander JE, Valentine SM, Thode HC, Henry MC: Association of training level and short-term cosmetic appearance of repaired lacerations. Acad Emerg Med 1996, 3:378-383.

231. Wyte CD, Adams SL, Cabel JA, Pearlman K, YArnold PR, Morkin M, Hott KA, Mathews JJ: Prospective evaluation of emergency medicine instruction for rotating first-postgraduate-year residents. Acad Emerg Med 1996, 3:72-76.

232. Magnusson AR, Hedges JR, Ashley P, Harper RJ: Resident educational time study: a tale of three specialties. Acad Emerg Med 1998, 5:718-725.

233. French D, Zwemer FL, Schneider S: The effects of the absence of emergency medicine residents in an academic emergency department. Acad Emerg Med 2002, 9:1205-1210.

234. Reisdorff EJ, Hayes OW, Reynolds B, Wilkinson KC, Overton DT, Wagner MJ, Kowalenko T, Protell D, Walker Gregory, Carlson: General competencies are Intrinsic to emergency medicine training: a multicenter study. Acad Emerg Med 2003, 10:1049-1053.

235. Dowd DM, Tarantino C, Barnett TM, Fitzmaurice L, Knapp JF: Resident efficiency in a pediatric emergency department. Acad Emerg Med 2005, 12:1240-1244.

236. Brennan DF, Silverstri S, Sun JY, Papa L: Progression of emergency medicine resident productivity. Acad Emerg Med 2007, 14:790-794.

237. Kessler CS, Stallings LA, Gonzales AA, Templeman TA: Combines residency training in emergency medicine and internal medicine: an update on career outcomes and job satisfaction. Acad Emerg Med 2009, 16:894-899.
238. Sexton JD, Heller MB, Patterson JD, Pronchik D, Melanson SW: Impact of emergency medicine residents on ancillary test utilization. Amer J Emerg Med 1998, 16:245-248.

239. Liu CC, Liang C, Yen DHT, Chern CH, Wang LM, Lee CH: Diagnosis of appendicitis in the ED: comparison of surgical and nonsurgical residents. Amer J Emerg Med 2001, 19:109-112.

240. Adams BD, Zeiler K, Jackson WO, Hughes B: Emergency medicine residents effectively direct inhospital cardiac arrest teams. Amer J Emerg Med 2005, 23:304-310.

241. Steele MT, Lewis LM, Schwab RA, Perez NM, Watson WA: Emergency medicine credentials in St Louis and Kansas City: does the presence of an emergency medicine residency program have a geographic difference? Ann Emerg Med 1996, 28:27-30.

242. McNamara RM, Kelly Jj: Cost of care in the emergency department: impact of an emergency medicine residency program. Ann Emerg Med 1992, 21:956-962.

243. Housel FB, Pearson D, Rhee KJ, Yamada J: Does the substitution of a resident for a flight nurse alter scene time? J Emerg Med 1995, 13:151-153.

244. Friedman L, Vilke GM, Chan TC, Hayden SR, Guss DA, Krishel SJ, Rosen P: Emergency department airway management before and after an emergency medicine residency. J Emerg Med 1999, 17:427-431.

245. Hall KN, Wakeman MA: Residency-trained emergency physicians: their demographics, practice evolution, and attrition from emergency medicine. J Emerg Med 1999, 17:7-15.

246. Branney SW, Pons PT, Markovchick VJ, Thomasson GO: Malpractice occurrence in emergency medicine: does residency training make a difference? J Emerg Med 2000, 19:99-105.

247. Taylor SF, Gerhardt RT, Simpson MP: An association between emergency medicine residencies and improved trauma patient outcome. I Emerg Med 2005, 29:123-127.

248. Levitt MA, Terregino CA, Lopez BL, Celi C: A national profile of resident research programs in emergency medicine. Acad Emerg Med 1999, 6:348-351.

249. DeBehnke D, O'Brien S, Leschke R: Emergency medicine resident work productivity in an academic emergency department. Acad Emerg Med 2000, 7:90-92.

250. Denizbasi A, Unluer EE: The role of the emergency medicine resident using the Alvarado score in the diagnosis of acute appendicitis compared with the general surgery resident. Eur J Emerg Med 2003, 10:296-301.

251. Dick W: Anglo-American vs. Franco-German emergency medical services system. Prehosp Dis Med 2003, 18:29-37.

252. Gallagher E, Henneman P: Changes in academic attributes associated with establishment of departments of emergency medicine. Acad Emerg Med 1998, 5:1091-1095.

253. Burdick W, Jouriles N, D'Onofrio G, Kass L, Mahoney J, Restifo K: Emergency medicine in undergraduate education. Acad Emerg Med 1998, 5:1105-1110

254. Davis M, Goldstein K, Nasser T, Assaf C: Peace through health: the role of health workers in preventing emergency care needs. Acad Emerg Med 2006, 13:1324-1327.

255. Michael G, O'Connor R: The importance of emergency medicine in organ donation: successful donation is more likely when potential donors are referred from the emergency department. Acad Emerg Med 2009, 16:850-858.

256. Chi C, Chang I, Wu W: Emergency department-based telemedicine. Amer J Emerg Med 1999, 17:408-411.

257. Reeder T, Locascio E, Tucker J, Czaplijski T, Benson N, Meggs W: ED utilization: the effect of changing demographics from 1992 to 2000. Amer J Emerg Med 2002, 20:583-587.

258. Sharieff G, Benjamin L, Mace S, Sacchetti A: Emergency physicians and the care of children. Amer J Emerg Med 2005, 23:890-893.

259. Macy Jr, Foundation J: The role of emergency medicine in the future of American medical care. Ann Emerg Med 1995, 25:230-233.

260. Bowles L: Recommendations for emergency medicine. Ann Emerg Med 1995, 25:234-235.

261. Kellermann A: Clinical emergency medicine, today and tomorrow. Ann Emerg Med 1995, 25:2235-238. 
262. Feied C, Smith M, Handler J, Kanhouwa M: Emergency medicine can play a leadership role in enterprise-wide clinical information systems. Ann Emerg Med 2000, 35:162-167.

263. American College of Emergency Physicians: Emergency medicine training, competency, and professional practice principles. Ann Emerg Med 2002, 39:468.

264. Babi F, Weiner D, Bhanji F, Davies F, Berry K, Barnett P: Advanced training in pediatric emergency medicine in the United States, Canada, United Kingdom, and Australia: an international comparison and resources guide. Ann Emerg Med 2005, 45:269-275.

265. Millard W: An American form of practice: societal contexts for the rise of emergency medicine. Ann Emerg Med 2008, 52:379-382.

266. Beemath A, Zalenski R: Palliative emergency medicine: resuscitating comfort care? Ann Emerg Med 2009, 54:103-105.

267. Gerhardt R, De Lorenzo R, Oliver J, Holcomb J, Pfaff J: Out-of-hospital combat casualty care in the current war in Iraq. Ann Emerg Med 2009, 53:169-174.

268. Antman E: The specialty of emergency medicine: needed now more than ever before. Ann Emerg Med 2008, 52:317-319.

269. AAEM Working Group: Position statement on the role of government in securing emergency medical care. Eur J Emerg Med 2002, 9:3-4.

270. Curry C: A perspective on developing emergency medicine as a specialty. Intl J Emerg Med 2008, 1:163-167.

271. Wai A, Chor C, Lee A, Sittambunka Y, Graham C, Rainer T: Analysis of trends in emergency department attendances, hospital admissions and medical staffing in a Hong Kong university hospital: 5-year study. Int/ J Emerg Med 2009, 2:141-148.

272. Yim V, Graham C, Rainer T: A comparison of emergency department utilization by elderly and younger adult patients presenting to three hospitals in Hong Kong. Int J Emerg Med 2009, 2:19-24.

273. Lishner D, Rosenblatt R, Baldwin L, Hart G: Emergency department use by the rural elderly. J Emerg Med 2000, 18:289-297.

274. Henderson S: Academic productivity in emergency medicine. J Emerg Med 2001, 21:71-73.

275. Goldfrank L: Personal and literary experiences in the development of an emergency physician. J Emerg Med 2003, 24:73-84.

276. Marx J: The rightness of emergency medicine. J Emerg Med 2004, 27:307-312.

277. Ciottone G, Old A, Nicholas S, Anderson P: Implementation of an emergency and disaster medical response training network in the commonwealth of independent states. J Emerg Med 2005, 29:221-229.

278. Hsu E, Dey C, Scheulen J, Bledsoe G, VanRooyen M: Development of emergency medicine administration in the people's republic of china. $J$ Emerg Med 2005, 28:231-236.

279. Edlich R: My revolutionary adventures in the development of modern emergency medical systems in our country. J Emerg Med 2008, 34:359-365.

280. Reames J, Handel D, Al-Assaf A, Hedges J: Rural emergency medicine: patient volume and training opportunities. J Emerg Med 2009, 37:172-176.

281. Barkin R: Pediatric emergency medicine: reflections on the past, present and future. J Emerg Med 2009, 36:1-2.

282. Hayden SR, Jouriles NJ, Rosen P: Requiem for "non-urgent" patients in the emergency department. J Emerg Med 2010, 38:381-383.

283. Hsia R, Razzak J, Tsa AC, Hirshon JM: Placing emergency care on the global agenda. Ann Emerg Med 2010, 56:142-149.

284. Tang N, Stein J, Hsia RY, et al: Trends and characteristics of US emergency department visits, 1997-2007. J Am Med Assoc 2010, 304:664-670.

285. Grossman MD: The role of emergency medicine physicians in trauma care in North America: evolution of a specialty. Scand J Trauma Resusc Emerg Med 2009, 17:37-43.

286. Hallas P: The effect of specialist treatment in Emergency Medicine; A survey of current experiences. Scand I Trauma Resusc Emerg Med 2006, 14:5-8.

doi:10.1186/1865-1380-4-44

Cite this article as: Holliman et al:: The efficacy and value of emergency medicine: a supportive literature review. International Journal of Emergency Medicine 2011 4:44.

\section{Submit your manuscript to a SpringerOpen ${ }^{\circ}$ journal and benefit from:}

- Convenient online submission

- Rigorous peer review

- Immediate publication on acceptance

- Open access: articles freely available online

- High visibility within the field

- Retaining the copyright to your article

Submit your next manuscript at $\gg$ springeropen.com 